\title{
PENINGKATAN KEMAMPUAN MENULIS TEKS EKSPOSISI DENGAN MENGGUNAKAN METODE CUSH WORD
}

\author{
Aliem Bahri \\ aliem_bahri@yahoo.co.id
}

\begin{abstract}
Abstrak
Penelitian ini merupakan penelitian tindakan kelas yang dilaksanakan dalam dua siklus, mulai dari (1) perencanaan, (2) pelaksanaan, (3) evaluasi, dan (4) refleksi. Subjek penelitian ini adalah siswa kelas X IPA-1 SMA Negeri I Sungguminasa Kabupaten Gowa sebanyak 29 orang yang terdiri dari 10 orang laki-laki dan perempuan 19 orang, dengan nilai rata-rata pada siklus I 53,59 dan siklus II mencapai nilai rata-rata 74,59. Teknik pengumpulan data yang digunakan adalah tekhnik tes dan tekhnik observasi

Hasil penelitian ini menunjukkan bahwa (1) perencanaan pembelajaran menulis teks eksposisi dapat dimaksimalkan dengan menggunakan metode cush word pada kriteria penilaian menulis teks eksposisi (kesesuaian judul dan isi, pengorganisasian isi, diksi dan ejaan, tata bahasa), (2) pelaksanaan pembelajaran menulis teks eksposisi melalui metode cush word dapat meningkatkan keterampilan menulis teks eksposisi yang terlihat pada munculnya motivasi, minat, serta adanya pembiasaan siswa dalam menuangkan ide atau gagasannya, (3) penilaian pembelajaran menulis teks eksposisi tidak saja difokuskan pada hasil pembelajaran, melainkan juga pada proses pembelajaran. Siswa yang sebelumnya kurang siap dan kurang aktif dalam pembelajaran menjadi lebih siap dan lebih aktif mengikuti pembelajaran. Penilaian tersebut merupakan perwujudan dari upaya maksimalisasi penilaian objektif berdasarkan penilaian evaluasi bahasa Indonesia pada pembelajaran keterampilan menulis khususnya menulis teks eksposisi.
\end{abstract}

\section{Kata Kunci: Menulis Eksposisi, Metode Cush Word}

\begin{abstract}
Singer study is classroom action research conducted hearts The prayer cycle, ranging from (1) Planning, (2) Implementation, (3) evaluation, and (4) reflection. Subject Research Singer is a Class X SMAN IPA-1 I Sungguminasa Gowa much as 29 orangutans orangutan Consisting Of the 10 men and women 19 orangutans, WITH The average value of ON CYCLE I CYCLE II reached 53.59 And the mean value average 74.59. Data collection The technique used is the technique tests and techniques of observation.

Results Cantor showed that (1) Planning Learning to write text exposition can be maximized WITH using methods cush said ON Criteria Evaluation write text exposition (FITNESS title and contents, organizing content, diction Dan Spelling, grammar), (2) Implementation of Learning to write text exposition through methods cush said can be improving the writing skills of text exposition seen ON emergence of motivation, interest, as well as their habituation Students hearts ideas OR ideas, (3) Assessment of Learning to write text exposition not only focused on the findings of learning, but Also ON Learning process. The former students Less And Less Active hearts Ready Learning Being better prepared and actively participating in learning. ASSESSMENT is the realization of Objective Assessment Of maximization efforts by Indonesian ON ASSESSMENT Evaluation of Learning writing skills, especially writing text exposition.
\end{abstract}

Keywords: Writing Exposition, Cush Methods Word 


\section{PENDAHULUAN}

Keterampilan menulis merupakan kemampuan yang paling sulit untuk dikuasai siswa dibandingkan dengan keterampilan berbahasa yang lain. Selain itu, pembelajaran keterampilan menulis tampaknya belum menggembirakan. Masalah yang timbul dalam proses pembelajaran menulis serta kemampuan siswa dalam menulis/mengarang yang belum memadai (masih rendah) sebagaimana uraian tersebut disebabkan oleh dua faktor utama, yaitu: faktor siswa dan faktor strategi pembelajaran yang diterapkan oleh guru. Adapun faktor yang berasal dari siswa, antara lain: (1) motivasi siswa dalam menulis sangat minim; (2) konsep atau bahan yang dimiliki siswa untuk dikembangkan jadi tulisan sangat terbatas; (3) kemampuan siswa menafsirkan fakta untuk ditulis sangat rendah; (4) kemampuan siswa menuangkan gagasan atau pikiran ke dalam bentuk kalimat-kalimat yang mempunyai kesatuan yang logis dan padu serta diikat oleh struktur bahasa. Adapun faktor yang berasal dari luar diri siswa, antara lain: (1) pokok bahasan menulis tidak memperoleh perhatian serius dari guru; (2) sarana dan metode atau strategi pembelajaran menulis belum efektif; (3) kurangnya hubungan komunikatif antara guru dan siswa serta siswa dengan siswa lainnya sehingga proses interaksi menjadi vakum. Hal tersebut mengisyaratkan bahwa dibutuhkan pembenahan dalam pembelajaran menulis.

Teks eksposisi tidak selalu terbagi atas bagian-bagian yang disebut pembukaan, pengembangan, dan penutup. Hal ini sangat tergantung dari sifat karangan dan tujuan yang hendak dicapai. Dengan demikian, penggunaan metode yang tepat tentu dapat memberikan hasil yang optimal dalam menulis teks eksposisi. Oleh karena itu, penulis mencoba menggunakan metode pembelajaran yaitu cush word (tebak kata) dalam pembelajaran menulis teks ekposisi. Seperti yang dipaparkan pada penjelasan sebelumnya, penulis memilih teks eksposisi sebagai bagian penelitian ini karena metode ini dapat diterapkan dalam pembelajaran menulis teks eksposisi karena dapat membantu peserta didik yang masih banyak mengalami kesulitan dalam mencari dan menuangkan ide dalam menulis teks eksposisi. Dengan demikian, penulis menggunakan metode ini dalam pembelajaran menulis teks eksposisi dengan judul "Peningkatan Kemampuan Menulis Teks Eksposisi dengan Menggunakan Metode Cush Word Pada Siswa Kelas X IPA-1 SMA Negeri I Sungguminasa"

\section{KAJIAN PUSTAKA}

Menulis atau (mengarang) adalah suatu proses yang menggunakan lambang-lambang (huruf) yang berisi pesan, gagasan, atau ide yang ingin disalurkan kepada orang lain. Pesan atau gagasan yang ingin disampaikan itu dapat berupa tulisan yang dapat menceritakan, melukiskan, memberi informasi, memengaruhi dan menambah pengetahuan. Hasil kegiatan mengarang seperti ini disebut karangan yang dapat berwujud sebuah wacana narasi, deskripsi, argumentasi, persuasi, dan eksposisi.

Tarigan (1994:19) mengemukakan bahwa menulis merupakan salah satu keterampilan berbahasa yang dipergunakan untuk berkomunikasi secara tidak langsung, tidak secara tatap muka dengan orang lain dengan orang lain.

Enre (dalam Muhammad Nawir 1994:2) mengemukakan bahwa menulis merupakan kemampuan mengungkapkan pikiran dan juga perasaan dalam tulisan yang efektif. Tentu saja segala lambang 
(tulisan) yang dipakai haruslah merupakan hasil kesepakatanpara pemakai bahasa yang satu dengan yang lainnya harus saling memahami. Dalam Kamus Besar Bahasa Indonesia (KBBI) dijelaskan bahwa menulis adalah kegiatan yang dilakukan dengan cara menuangkan pesan (isi pikiran) melalui kalimat melalui tulisan agar dibaca dan dimengerti orang lain, Umi Chulsum dkk, 2006: 752).

Dari beberapa uraian di atas dapatlah disimpulkan bahwa menulis merupakan suatu bentuk komunikasi yang tidak langsung untuk menyampaikan gagasan penulis kepada pembaca dengan menggunakan media bahasa yang dilengkapi dengan unsur suprasegmental.

Kegiatan penulis merupakan keterampilan mekanis yang dapat dipahami dan dipelajari. Menulis sebagai suatu proses terdiri atas beberapa tahapan. Tompkinas dan Hoskinsson (dalam Sirajuddin 1994:89) menguraikan lima tahapan menulis, yaitu pramenulis, pengedrafan, perbaikan, penyuntingan, dan publikasi, siswa diberi kesempatan menentukan apa yang akan ditulis. Tujuan menulis dan karangka tulisan. Setelah siswa menentukan apa yang akan ditulis dan sistematika tulisan, siswa mengumpulkan bahan-bahan tulisan dengan menggunakan buku-buku dan sumber lainnya untuk memudahkan dalam penulisan.

Menurut Tarigan (dalam Ahmad Andis 1987:36) bahwa paragraf yang baik atau berkualitas harus memilih syarat-syarat : (1) isi paragraf berpusat hanya pada satu hal, (2) paragraf harus koheren dan unity, (3) kaliamat topik harus dikembangkan dengan jelas dan sempurna, (4) struktur paragraf harus bervariasi, dan (5) paragraf tertulis dalam bahasa Indonesia yang benar.

Dalam teks eksposisi dikenal beberapa jenis pembagian, antara lain, defenisi dan analisis. Defenisi merupakan jenis eksposisi yang sering digunakan karena mendasari penjelasan yang disajikan dalam suatu karangan. Dapat atau tidaknya pembaca memahami penjelasan yang disajikan dalam suatu karangan, antara lain bergantung pada dapat atau tidaknya penulis mengemukakan defenisi yang memadai. Analisis merupakan wacana eksposisi yang menjelaskan suatu masalah dengan mengemukakan uraian keseluruhan masalah menjadi bagian-bagian sehingga pembaca dapat memahami masalah tersebut.

Eksposisi adalah ragam wacana yang dimaksudkan untuk menerangkan, menyampaikan, atau menguraikan sesuatu hal yang dapat memperluas atau menambah pengetahuan dan pandangan pembacanya. Sasarannya adalah menginformasikan sesuatu tanpa ada maksud mempengaruhi pikiran , perasaan, dan sikap pembacanya. Fakta dan ilustrasi yang disampaikan penulis sekedar memperjelas apa yang akan disampaikan ( Suparno dan Yunus, 2002:110).

Syafi'ie (dalam Ernawati, 1988:25) menandakan bahwa tujuan tulisan eksposisi adalah menyampaikan faktafakta secara teratur dan saling bertautan. Hal itu untuk menjelaskan sesuatu ide, istilah, masalah proses, atau sebab-akibat. Penulis eksposisi harus mampu mengembangkan suatu objek secara rinci sehingga segala aspek atau unsur yang dianggap perlu untuk dijelaskan benarbenar dipahami maksudnya.

Menurut Taylor (dalam Ernawati 1982:34) siswa yang belajar membuat ringkasan mampu mengingat wacana eksposisi lebih baik dan mereka mempunyai kepekaan yang lebih besar terhadap pengorganisasian wacana tulisan eksposisi supaya lebih jelas dapat dilengkapi dengan deskripsi, contoh: 
gambar, angka-angka, grafik, dan sebagainya.

\section{Karakteristik Karangan Eksposisi}

Menurut Suparno dan Yunus (2002:5.4) karangan eksposisi adalah karangan yang bertujuan utama untuk memberitahu, mengupas, menguraikan, atau menerangkan sesuatu. Dalam karangan eksposisi, masalah yang dikomunikasikan terutama adalah informasi. Lebih lanjut Suparno \& Yunus mengatakan bahwa sangat mungkin sesuatu yang dikomunikasikan itu, berupa (1) data faktual, misalnya tentang suatu kondisi yang benar-benar bersifat historis, tentang bagaimana sesuatu (misalnya suatu mesin bekerja, dan bagaimana tentang suatu operasi diperkenalkan, (2) suatu analisis atau suatu penafsiran yang objektif terhadap seperangkat fakta, dan (3) mungkin sekali berupa fakta tentang seseorang yang berpegang teguh pada suatu pendirian yang khusus, asalkan tujuan utamanya adalah untuk memberikan informasi.

\section{Langkah-Langkah Eksposisi}

Penyusunan

Langkah-langkah yang ditempuh dalam membuat eksposisi dapat dilakukan dalam tiga hal pokok, yaitu (1) menentukan topik karangan, menentukan tujuan penulisan, dan (3) merencanakan paparan dengan membuat kerangka yang lengkap dan tersusun baik (Suparno \& Yunus, 2002:5.7).

Sebelum memulai menulis, topik atau tema eksposisi harus sudah ditentukan. Topik itu pikiran, gagasan, atau ide yang menjadi pusat dan akan menjiwai seluruh eksposisi. Topik inilah yang akan dikembangkan menjadi karangan. Oleh karena itu, topik tidak boleh terlalu luas, karena akan menjadikan karangan terlalu panjang, atau menjadi karangan dangkal tidak menarik. Misalnya, topik "Pesawat Terbang di Indonesia". Topik ini sangat luas, sehingga akan sangat banyak yang akan dipaparkan. Oleh karena itu, topik harus disederhanakan atau dibatasi supaya menjadi lebih sempit. Dengan demikian, akan lebih mudah mengolahnya menjadi karangan yang cukup mendalam.

\section{Teknik Penulisan Eksposisi}

Agar dapat menulis teks eksposisi dengan baik, perlu pemahaman dan penguasaan tekhnik menulis eksposisi. Menurut Rofi'uddin \& Zuhdi (1998/1999:173) dalam Ernawati (2013), ada enam cara dalam menulis eksposisi, yaitu (1) panjang karangan yang disusun, bisa diperkirakan dengan jumlah halaman atau jumlah kata-kata, (2) tujuan penulisan yakni, memberitahu, menjelaskan, atau mengajari cara melakukan sesuatu, (3) kesempatan untuk menulis, yaitu tersedianya sumber penulisan, waktu dan dana, (4) kondisi pembaca yang dituju, yakni umur, jenis kelamin, pengetahuannya, lapisan sosialnya, (5) pengetahuan dan pengalaman yang berkaitan dengan masalah yang akan ditulis, yakni seberapa luas dan dalam pengetahuan yang akan ditulis itu, (6) hal-hal yang paling utama mengenai masalah yang hendak disajikan kepada para pembaca.

Di antara enam butir di atas, yang benar-benar harus diperhatikan adalah butir 2 dan butir 4 . Butir 2 berkaitan dengan tujuan menulis, yaitu untuk memberitahu, menjelaskan atau mengajari pembaca melakukan sesuatu. Tujuan ini menentukan apa yang akan ditulis dan bagaimana mengorganisasikannya. Butir 4 berkaitan kondisi pembaca yang dimaksudkan dalam kaitannya dengan apa yang akan 
ditulis. Dalam hal ini, harus dapat memperkirakan setepat mungkin apa yang sudah diketahui oleh pembaca mengenai hal yang akan ditulis.

\section{Metode Cush Word (Tebak Kata)}

Tebak kata merupakan penyampaian materi ajar dengan menggunakan katakata singkat dalam bentuk kartu permainan sehingga anak dapat menerima pesan pembelajaran melalui kartu itu. Untuk itu, buatlah kartu yang didalamnya mengandung berbagai pertanyaan yang membutuhkan satu kartu jawaban yang dapat mewakili dari seluruh pertanyaan atau pertanyaan yang ada.

Menebak kata merupakan aktivitas pembelajaran yang pertama dan utama dalam mewujudkan keberhasilan proses belajar mengajar. Melalui tebak kata, siswa diarahkan untuk memahami dan mengetahui pesan-pesan yang terkandung dalam materi. Jadi dengan mampunya siswa menebak kata berarti mencerminkan kemampuan siswa dalam menguasai dan memahami materi yang ada.

\section{Langkah-langkah Metode Crush Word (Tebak Kata)}

1. Guru mempersiapkan kartu yang akan digunakan dalam proses pembelajaran.

2. Guru menjelaskan kompetensi yang ingin dicapai atau materi pelajaran selama \pm 45 menit.

3. Guru menyuruh peserta didik berdiri berpasangan di depan kelas.

4. Seorang peserta didik diberi kartu yang berukuran $10 \times 10 \mathrm{~cm}$ yang nantinya dibacakan kepada pasanganya. Seorang peserta didik lainnya diberikan kartu dengan ukuran $5 \times 2 \mathrm{~cm}$ yang isinya tidak boleh dibaca (kertasnya dilipat) kemudian ditempelkan di dahi atau diselipkan ditelinga (dengan syarat siswa yang memegang kartu yang berukuran $10 \times 10 \mathrm{~cm}$ bisa melihat apa jawabannya).

5. Peserta didik yang memegang kartu 10x10 cm membacakan kata-kata yang tertulis didalamnya sementara pasanganya menebak apa yang dimaksud dalam kartu 10x10 cm. Jawaban tepat apabila sesuai isi kartu yang berukuran $5 \times 2 \mathrm{~cm}$ tersebut.

6. Apabila jawabannya tepat (sesuai yang tertulis dikartu) maka pasangan itu boleh duduk. Bila belum tepat pada waktu yang ditetapkan, peserta didik boleh mengarahkan dengan kata-kata lain, dengan syarat tidak langsung memberikan jawabannya.

7. Pengambilan kesimpulan.

8. Penutup.

\section{METODE PENELITIAN}

\section{Jenis Penelitian}

Penelitian ini merupakan penelitian tindakan kelas (classroom action research) yang bertujuan untuk meningkatkan kemampuan menulis teks eksposisi pada siswa Kelas X IPA-1 SMA Negeri I Sungguminasa melalui metode cush word.

\section{Lokasi dan Subjek Penelitian}

Penelitian ini akan dilaksanakan di Kelas X IPA-1 SMA Negeri I Sungguminasa yang terletak di Kabupaten Gowa, dengan jumlah siswa 29 orang, yang terdiri dari laki-laki berjumlah 10 orang dan perempuan 19 orang.

\section{Prosedur Penelitian}


Prosedur penelitian ini dirancang atas dua siklus yaitu, siklus pertama ( 2 minggu) $4 \mathrm{x}$ pertemuan dan, siklus kedua (2 minggu) $4 \mathrm{x}$ pertemuan.

Prosedur penelitian tindakan kelas ini dilaksanakan sesuai dengan perubahan yang ingin dicapai dan pelaksanaannya dilaksanakan menurut prosedur tahapan yaitu, tahap perencanaan, tahap pelaksanaan, tahap observasi, evaluasi, dan tahap refleksi.

\section{Instrumen Penelitian}

Instrumen yang digunakan dalam penelitian ini, yaitu lembar observasi dan tes tentang menulis teks ekposisi. Observasi digunakan untuk memperoleh data aktivitas guru dan siswa. Tes digunakan untuk memperoleh data kemampuan menulis teks eksposisi melalui metode cush word pada siswa kelas $\mathrm{X}$ IPA-1 SMA Negeri I Sungguminasa.

\section{Teknik Pengumpulan Data}

Cara pengambilan data dalam penelitian ini adalah sebagai berikut :

1. Teknik tes

Data hasil belajar diambil dengan memberikan tes essay berupa pertanyaan mengenai keterampilan menulis teks eksposisi kepada siswa setiap akhir siklus.

2. Teknik Observasi

Observasi dilakukan selama proses pembelajaran untuk memperoleh informasi proses pembelajaran dalam menulis eksposisi.

\section{Teknik Analisis Data}

Data yang diperoleh melalui bentuk tes akan dianalisis secara kuantitatif, sedangkan data yang diperoleh melalui observasi, pencatatan lapangan, akan dianalisis secara kualitatif.

\section{HASIL PENELITIAN DAN PEMBAHASAN}

\section{A. Hasil Penelitian}

\section{Hasil Tes siklus I}

Pada siklus ini, hasil kemampuan menulis siswa diukur dari tes evaluasi yang diberikan setelah menyelesaikan satu pokok bahasan. Hasil analisis deskriftif skor siswa yang diperoleh setelah penggunaan metode cush word dapat dilihat dari tabel 4.1 berikut :

Tabel 4.1 Statistik Skor Hasil kemampuan Menulis Eksposisi Siswa Kelas X IPA-1 SMA Negeri I Sungguminasa pada Siklus I

\begin{tabular}{cc}
\hline Statistik & $\begin{array}{c}\text { Nilai } \\
\text { Statistik }\end{array}$ \\
\hline Jumlah Siswa & 29 \\
\hline Skor Ideal & 100 \\
\hline Nilai Maksimum & 80 \\
\hline Nilai Minimum & 30 \\
\hline Rentang Skor & 50 \\
\hline Skor Rata-rata & 53,59 \\
\hline Standar Deviasi & 14,09 \\
\hline
\end{tabular}

Berdasarkan Tabel 4.1 diperoleh bahwa skor rata-rata hasil kemampuan menulis eksposisi siswa kelas X IPA-1 SMA Negeri I Sungguminasa setelah menggunakan metode Cush Word pada siklus I adalah 53,59 dari skor ideal yang mungkin dicapai yaitu 100. Skor tertinggi yakni 80 dan terendah 30 dengan standar deviasi 14,09.

\section{Hasil Tes siklus II}

Pada siklus II ini dilaksanakan tes hasil menulis eksposisi dengan bentuk tes essay. Tes hasil belajar tersebut dilaksanakan setelah penyajian satu pokok bahasan yaitu pengertian eksposisi, jenis-jenis eksposisi, ciri-ciri 
eksposisi dan langkah-langkah menyusun eksposisi. Adapun data skor hasil menulis eksposisi siswa siklus II dapat dilihat pada tabel berikut:

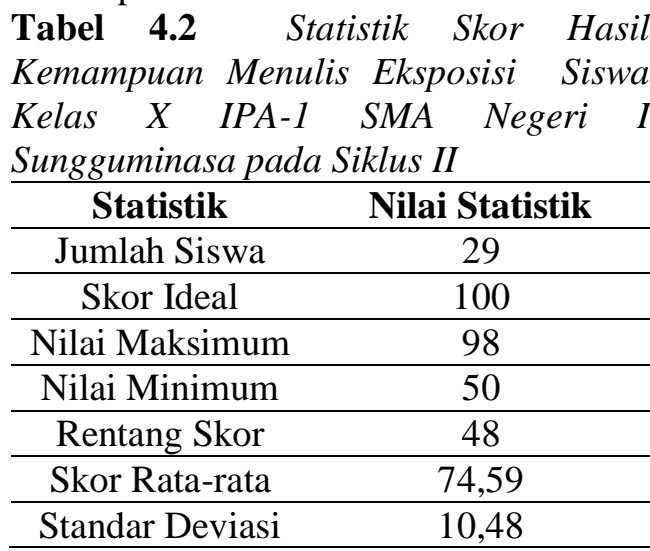

\section{Analisis data kualitatif}

Di samping peningkatan kemampuan menulis eksposisi, selama penelitian pada siklus I dan siklus II tercatat sejumlah perubahan yang terjadi selama proses belajar mengajar berlangsung. Perubahan tersebut merupakan data kualitatif yang diperoleh dari lembar observasi pada setiap pertemuan yang dicatat pada tiap siklus untuk mengetahui perubahan kesiapan siswa dalam mengikuti proses belajar mengajar selama penelitian ini berlangsung.

\section{Siklus I}

Data aktivitas siswa pada siklus I diperoleh melalui hasil pengamatan aktivitas dan sikap siswa selama proses pembelajaran di setiap pertemuan. Adapun deskripsi aktivitas siswa pada siklus I dapat dilihat pada Tabel 4.3 berikut:

Tabel 4.3 Distribusi Frekuensi Aktivitas dan Sikap Siswa pada Siklus I

\begin{tabular}{|c|c|c|c|c|c|c|}
\hline \multirow[t]{2}{*}{ No } & \multirow[t]{2}{*}{ Kriteria Penilaian } & \multicolumn{4}{|c|}{ Pertemuan } & \multirow{2}{*}{$\begin{array}{c}\text { Persentase } \\
(\%)\end{array}$} \\
\hline & & 1 & 2 & 3 & $\sum$ & \\
\hline 1. & Jumlah siswa yang hadir & 26 & 21 & 25 & 72 & 82,75 \\
\hline 2. & $\begin{array}{l}\text { Siswa yang memperhatikan } \\
\text { pembahasan materi pembelajaran }\end{array}$ & 24 & 19 & 23 & 66 & 75,86 \\
\hline 3. & $\begin{array}{l}\text { Siswa yang mengajukan pertanyaan } \\
\text { tentang materi yang belum } \\
\text { dimengerti }\end{array}$ & 3 & 5 & 6 & 14 & 16,09 \\
\hline 4. & $\begin{array}{l}\text { Siswa yang mengerjakan soal } \\
\text { latihan }\end{array}$ & 10 & 12 & 14 & 36 & 33,33 \\
\hline 5. & $\begin{array}{l}\text { Siswa yang melakukan kegiatan } \\
\text { lain pada saat proses belajar } \\
\text { mengajar berlangsung }\end{array}$ & 2 & 2 & 2 & 6 & 6,89 \\
\hline
\end{tabular}

Berdasarkan Tabel 4.3 di atas diperoleh bahwa dari 29 siswa kelas $\mathrm{X}$ IPA-1 SMA Negeri I Sungguminasa yang terlampir pada lembar observasi dan absensi siswa, kehadiran siswa rata-rata pada siklus I mencapai $82,75 \%$. Siswa yang memperhatikan pembahasan materi pembelajaran rata-rata $75,86 \%$, siswa yang mengajukan pertanyaan tentang materi yang belum dimengerti rata-rata
16,09\%. Kemudian Siswa yang mengerjakan soal latihan mencapai $41,38 \%$. Siswa yang melakukan kegiatan lain pada saat proses belajar mengajar berlangsung mencapai $6,89 \%$.

\section{Siklus II}

Data aktivitas siswa pada siklus II diperoleh melalui hasil pengamatan 
aktivitas dan sikap siswa selama proses pembelajaran di setiap pertemuan. Adapun deskripsi aktivitas siswa pada siklus II dapat dilihat pada Tabel 4.4 berikut:

Tabel 4.4 Distribusi Frekuensi Aktivitas dan Sikap Siswa pada Siklus II

\begin{tabular}{|c|c|c|c|c|c|c|}
\hline \multirow[t]{2}{*}{ No } & \multirow[t]{2}{*}{ Kriteria Penilaian } & \multicolumn{4}{|c|}{ Pertemuan } & \multirow{2}{*}{$\begin{array}{c}\text { Persen-tase } \\
(\%)\end{array}$} \\
\hline & & 1 & 2 & 3 & $\sum$ & \\
\hline 1. & Jumlah siswa yang hadir & 28 & 28 & 28 & 84 & 96,55 \\
\hline 2. & $\begin{array}{l}\text { Siswa yang memperhatikan } \\
\text { pembahasan materi pembelajaran }\end{array}$ & 27 & 29 & 29 & 85 & 97,70 \\
\hline 3. & $\begin{array}{l}\text { Siswa yang mengajukan pertanyaan } \\
\text { tentang materi yang belum } \\
\text { dimengerti }\end{array}$ & 5 & 8 & 9 & 22 & 25,29 \\
\hline 4. & $\begin{array}{l}\text { Siswa yang mengerjakan soal } \\
\text { latihan }\end{array}$ & 10 & 12 & 16 & 38 & 43,68 \\
\hline 5. & $\begin{array}{l}\text { Siswa yang melakukan kegiatan } \\
\text { lain pada saat proses belajar } \\
\text { mengajar berlangsung }\end{array}$ & 2 & 1 & - & 3 & 3,45 \\
\hline
\end{tabular}

Berdasarkan Tabel 4.4 di atas diperoleh bahwa dari 29 siswa kelas X IPA-1 SMA Negeri I Sungguminasa yang terlampir pada absen kelas, kehadiran siswa rata-rata mencapai $96,55 \%$. Siswa yang memperhatikan pembahasan materi pembelajaran rata-rata $97,70 \%$, Siswa yang mengajukan pertanyaan tentang materi yang belum dimengerti rata-rata $25,29 \%$. Kemudian Siswa yang melakukan kegiatan lain pada saat proses belajar mengajar berlangsung mencapai $3,45 \%$, Siswa yang mengerjakan soal latihan mencapai $43,68 \%$.

\section{SIMPULAN DAN SARAN}

\section{Simpulan}

Berdasarkan hasil penelitian disimpulkan bahwa pembelajaran menulis eksposisi melalui metode cush word pada siswa kelas X IPA-1 SMA Negeri I Sungguminasa dapat terlaksana dengan baik dan terjadi peningkatan pada pembelajaran menulis eksposisi siswa setelah diadakan tindakan selama dua siklus. Dari hasil penilaian dalam pembelajaran menulis eksposisi melalui metode cush word siswa kelas X, pada siklus I dan siklus II dilihat dari penilaian aspek isi, aspek kosakata penggunaan bahasa dan hasil observasi. Skor rata-rata pada siklus I siswa memperoleh 53,59 sedangkan pada akhir siklus II skor ratarata yang dicapai siswa adalah 74,59. Pada siklus I masih dikategorikan rendah karena belum mencapai Ketuntasan Kriteria Minimal (KKM), setelah diterapkan kembali pembelajaran pada siklus II sudah meningkat karena mencapai Ketuntasan Kriteria Minimal (KKM) sebesar $70 \%$.

\section{Saran}

Hal-hal yang dapat disarankan berdasarkan hasil penelitian tindakan kelas ini sebagai berikut :

1. Bagi siswa kelas X IPA-1 SMA Negeri I Sungguminasa yang telah mencapai hasil baik agar berupaya mempertahankannya. Siswa yang belum mencapai hasil baik agar berupaya untuk meningkatkan hasil menulis dengan cara selalu berlatih 
dalam penulisan eksposisi dan memperbaiki kosakata dan penggunaan bahasa yang tepat.

2. Perencanaan yang diterapkan oleh guru harus sesuai dengan langkah kegiatan pembelajaran dan memungkinkan siswa dapat melaksanakan tugas menulis eksposisi. Dengan cara ini, diharapkan kemampuan menulis siswa memiliki motivasi untuk menulis lebih meningkat.

3. Sebagai tindak lanjut penerapan pembelajaran bahasa Indonesia dengan menggunakan metode $\mathrm{Cush}$ Word, diharapkan guru lebih kreatif dalam menyajikan pelajaran agar siswa dapat lebih termotivasi, dan lebih terlatih dalam berpikir untuk menemukan penyelesaian soal/masalah khususnya dalam menulis.

\section{DAFTARA PUSTAKA}

Ahmad Andis. 2010. Peningkatan Kemampuan Menulis Paragraf Melalui Media Gambar Siswa Kelas V SDN 75 Palopo. Tesis tidak diterbitkan. Unismuh Makassar.

Akhadiah, Sabarti,dkk. 1998. Pembinaan Kemampuan Menulis Bahasa Indonesia. IKIP Jakarta. Erlangga.

Arikunto, Suharsimin. 2008. Penelitian Tindakan Kelas. Jakarta: Bumi Aksara.

Chulsum Umi, dkk. 2006. Kamus Besar bahasa Indonesia. Surabaya: Kashiko contoh.html.

D.Ph. Sukardi, 2003. Metodologi Penelitian
Pendidikan:Kompetensi dan Praktiknya. Jakarta: Bumi Aksara.

Ernawati. 2013. Peningkatan Kemampuan Menulis Karangan Eksposisi Melalui Strategi Rangsangan Visual Siswa Kelas VIII SMP Negeri I Bungoro Kab. Pangkep. Skripsi tidak diterbitkan. Unismuh Makassar

Http://www.pojok

manfaat.com/2013/05/paragraf eksposisi-pengertian-ciri-jenis-

Irfan. 2014. Peningkatan Kemampu Menulis Paragraf Ekposw. Dengan Model Pembelajaran Cooperative Integrated Reading And Composition(CIRC). Terhadap Siswa Kelas X/A SMA Negeri I Liukang Tupabbiring Kabupaten Pangkep

Muhammad Nawir. 2012. Peningkatan Kemampuan Menulis Paragraf Persuasif Melalui penerapan Teknik Mind Mapping Pada Siswa Kelas VII MTS Muhammadiyah Tallo Makassar. Skripsi tidak diterbitkan. Unismuh Makassar.

Munirah. 2012. Bahan Ajar Karya Tulis Ilmiah. Diktat, Unismuh Makassar

Poyoth-P. blogspot.com/2012/11/modelpembelajaran-guided-teachinghtml

Rahmi. 2011. Penerapan Teknik Mind Mapping Dalam Meningkatkan Kemampuan Menulis Karangan Persuasif Siswa Kelas XI SMA Muhammadiyah Wilayah 
Makassar. Skripsi tidak diterbitkan. Unismuh Makassar.

Said, D. M. M. Ide. 2008. Aspek kebahasaan dan Tata Cara Penulisan. Makalah. Worshop Penulisan Bahan Ajar. Universitas Muhammadiyah Makassar.

Sirajuddin. 2012. Peningkatan Pembelajaran keterampilan Menulis Karangan Argumentasi dengan Menggunakan Metode Brainstorming Siswa Kelas $X$ SMA Negeri I Kelara. Skripsi tidak diterbitkan.Unismuh Makassar

Suparno \& Yunus, M. 2002. Keterampilan Dasar Menulis. Jakarta: Universitas Terbuka, Depdiknas.

Syamsuddin, AR. 2009. Kompetensi Berbahasa dan Sastra Indonesia 3. Departemen Pendidikan Nasional.

Tarigan, Henry Guntur. 1994. Menulis Sebagai suatu Keterampilan Berbahasa. Bandung : Angkasa. 